\title{
UPR-mediated TRIB3 expression correlates with reduced AKT phosphorylation and inability of interleukin 6 to overcome palmitate-induced apoptosis in RINm5F cells
}

\author{
José Edgar Nicoletti-Carvalho*, Tatiane C Araújo Nogueira*, Renata Gorjão ${ }^{1}$, Carla Rodrigues Bromati, \\ Tatiana S Yamanaka, Antonio Carlos Boschero ${ }^{2}$, Licio Augusto Velloso ${ }^{3}$, Rui Curi, Gabriel Forato Anhế ${ }^{4}$ \\ and Silvana Bordin \\ Department of Physiology and Biophysics, Institute of Biomedical Sciences, University of Sao Paulo, Prof. Lineu Prestes Ave \#1524. ICB 1- Room 125, 05508-900 \\ Sao Paulo, SP, Brazil \\ ${ }^{1}$ Institute of Physical Activity Sciences and Sports, Cruzeiro do Sul University, Sao Paulo, SP, 03342-000, Brazil \\ Departments of ${ }^{2}$ Physiology and Biophysics, Institute of Biology, 13083-862, ${ }^{3}$ Internal Medicine, Faculty of Medical Sciences and ${ }^{4}$ Pharmacology, Faculty of \\ Medical Sciences, State University of Campinas, Campinas, SP, 13083-887, Brazil \\ (Correspondence should be addressed to S Bordin; Email: sbordin@icb.usp.br) \\ *(J E Nicoletti-Carvalho and T C Araújo Nogueira contributed equally to this work)
}

\begin{abstract}
Unfolded protein response (UPR)-mediated pancreatic $\beta$-cell death has been described as a common mechanism by which palmitate (PA) and pro-inflammatory cytokines contribute to the development of diabetes. There are evidences that interleukin 6 (IL6) has a protective action against $\beta$-cell death induced by pro-inflammatory cytokines; the effects of IL6 on PA-induced apoptosis have not been investigated yet. In the present study, we have demonstrated that PA selectively disrupts IL6-induced RAC-alpha serine/threonine-protein kinase (AKT) activation without interfering with signal transducer and activator of transcription 3 phosphorylation in RINm5F cells. The inability of IL6 to activate AKT in the presence of PA correlated with an inefficient protection against PA-induced apoptosis. In contrast to PA, IL6 efficiently reduced apoptosis induced by proinflammatory cytokines. In addition, we have demonstrated
\end{abstract}

that IL6 is unable to overcome PA-stimulated UPR, as assessed by activating transcription factor 4 (ATF4) and C/EBP homologous protein (CHOP) expression, X-box binding protein-1 gene mRNA splicing, and pancreatic eukaryotic initiation factor- $2 \alpha$ kinase phosphorylation, whereas no significant induction of UPR by pro-inflammatory cytokines was detected. This unconditional stimulation of UPR and apoptosis by PA was accompanied by the stimulation of CHOP and tribble3 (TRIB3) expression, irrespective of the presence of IL6. These findings suggest that IL6 is unable to protect pancreatic $\beta$-cells from PA-induced apoptosis because it does not repress UPR activation. In this way, CHOP and ATF4 might mediate PA-induced TRIB3 expression and, by extension, the suppression of IL6 activation of pro-survival kinase AKT.

Journal of Endocrinology (2010) 206, 183-193

\section{Introduction}

Obesity and insulin resistance are tightly associated with the onset of type 2 diabetes mellitus (T2DM), possibly due to increased circulating levels of glucose and free fatty acids (FFAs), which are known to induce $\beta$-cell apoptosis, a phenomenon known as glucolipotoxicity (Donath et al. 2005). However, the precise relevance and the mechanisms by which FFAs trigger $\beta$-cell death are still unclear. In contrast to T2DM, type 1 diabetes mellitus (T1DM) is well defined by pancreatic $\beta$-cell injury due to the action of pro-inflammatory cytokines, such as interleukin-1 $\beta$ (IL-1 $\beta$ ), interferon$\gamma(\mathrm{IFN}-\gamma)$, and tumour necrosis factor- $\alpha(\mathrm{TNF}-\alpha)$, which are released by infiltrated immune cells (Cnop et al. 2005).

Several recent studies have described that both proinflammatory cytokines and FFAs induce an imbalance between endoplasmic reticulum (ER) folding demand and capacity in the $\beta$-cells, the so-called ER stress. The cellular consequence of the ER stress is the unfolded protein response (UPR) activation. The initial goal of UPR is to accomplish ER folding rate to the increased demand. However, if the stress persists, the termination phase of UPR targets apoptosis (Ron \& Walter 2007). UPR-activated apoptosis occurs by a yet-unrevealed mechanism, but the increase in c-Jun $\mathrm{N}$-terminal kinase activation and $\mathrm{C} / \mathrm{EBP}$ homologous protein (CHOP) expression is likely to be the essential step (Kharroubi et al. 2004, Akerfeldt et al. 2008).

Great attention is being paid to IL6 produced by adipocytes due to its possible involvement in the onset of T2DM (Herder et al. 2006). IL6 production is directly proportional to adipose tissue mass, which generates more than 30\% of its serum levels (Mohamed-Ali et al. 1997). 
Although leading to insulin resistance in peripheral tissues (Glund \& Krook 2008), IL6 has been shown to play a complex role in pancreatic $\beta$-cell death in diabetes. IL6 was described to counteract pancreatic $\beta$-cell apoptosis induced by pro-inflammatory cytokines (Park et al. 2003, Choi et al. 2004), and to increase cell death in primary islets treated with FFAs (Ellingsgaard et al. 2008). Paradoxically, it was observed that the incidence of T1DM in non-obese diabetic (NOD) mice decreased when the mice were crossed with transgenic mice overexpressing IL6 (DiCosmo et al. 1994).

In spite of the evident increased levels of IL6 in obese and insulin-resistant patients and the diabetogenic properties of this cytokine, no data are available regarding the ability of IL6 to modulate FFA-induced ER stress in pancreatic $\beta$-cells. In order to assess this issue, we investigated whether IL6 modulates palmitate (PA)-induced $\beta$-cell apoptosis by focusing on IL6 intracellular signaling pathways and the main branches of UPR.

\section{Materials and Methods}

\section{RINm $5 \mathrm{~F}$ cell culture and incubation}

The rat insulinoma cell line RINm5F was cultured in RPMI1640 medium $(11 \cdot 1 \mathrm{mM}$ glucose and $10 \% \mathrm{FBS})$ as described previously (Anhê et al. 2007). For the time-course and doseresponse experiments, the cells were incubated for $30 \mathrm{~min}$ at $37^{\circ} \mathrm{C}$ with Krebs-bicarbonate buffer (KBB) containing $0.3 \mathrm{mM}$ glucose prior to the incubation with rat IL6 (Sigma). For the time-course and dose-response experiments, incubation with IL6 was carried out using KBB at different intervals and at several concentrations (indicated in the figures) respectively. PA (Sigma) treatment at prolonged intervals was carried out in a serum-free medium containing $1 \%$ of fatty acid-free BSA. Cells were pre-treated with IL6 $(100 \mathrm{ng} / \mathrm{ml})$ for $24 \mathrm{~h}$, and then the medium was replaced with a fresh medium containing IL6 alone or in combination with PA, followed by incubation for an additional $12 \mathrm{~h}$. PA was dissolved in $95 \%$ ethanol to a concentration of $100 \mathrm{mM}$, and heated to $60^{\circ} \mathrm{C}$ for $30 \mathrm{~min}$. Alcoholic PA solution was added to the culture medium to yield a final concentration of $250 \mu \mathrm{M}$ (bound + unbound). Ethanol at a final concentration of $0 \cdot 25 \%(\mathrm{v} / \mathrm{v})$ was added to all the cultures in which PA was absent.

Treatment with pro-inflammatory cytokine mixture (CM) was carried out in RPMI-1640 medium containing $11.1 \mathrm{mM}$ glucose and $10 \%$ FBS. Incubation that was carried out using CM lasted for $24 \mathrm{~h}$, and was preceded by a $24 \mathrm{~h}$ incubation with IL6. Thus, in these experiments, the total interval during which the cells were exposed to IL6 was $48 \mathrm{~h}$, and during the last $24 \mathrm{~h}$ of this time period, the cells were grown in the presence or absence of $\mathrm{CM}$. CM was prepared using a combination of IL1 $\beta(60 \mathrm{U} / \mathrm{ml}, 4.4 \mathrm{ng} / \mathrm{ml})$, IFN- $\gamma$ $(14 \mathrm{U} / \mathrm{ml}, 10 \cdot 3 \mathrm{ng} / \mathrm{ml})$, and TNF- $\alpha(185 \mathrm{U} / \mathrm{ml}, 4 \cdot 4 \mathrm{ng} / \mathrm{ml}$; Souza et al. 2008).
Transfection of RINm5F cells with small interfering RNA (siRNA) targeted at CHOP (sc-156118, Santa Cruz Biotechnology, Santa Cruz, CA, USA) or scrambled control siRNA (sc-37007, Santa Cruz Biotechnology) was performed as described previously (Anhê et al. 2010). Briefly, the cells were washed twice with a serum-free medium (Opti-MEM, Invitrogen), and were then incubated with $1 \mathrm{ml}$ of the same medium containing the siRNA (final concentration of $80 \mathrm{nM}$ ) previously mixed with $2 \mu \mathrm{l}$ Lipofectamine 2000 (Invitrogen), or Lipofectamine only (CTL). After $7 \mathrm{~h}, 1 \mathrm{ml}$ of RPMI medium containing 20\% FBS and $22.2 \mathrm{mM}$ glucose was added to the culture containing siRNAs and Lipofectamine, and the cells were incubated for an additional $12 \mathrm{~h}$ (final concentrations of FBS and glucose were $10 \%$ and $11.1 \mathrm{mM}$ respectively). Thereafter, the cells were allowed to grow for $60 \mathrm{~h}$ in RPMI medium (11.1 mM glucose and $10 \%$ FBS) that was replaced every $24 \mathrm{~h}$. After this period, the cells were treated with PA for $12 \mathrm{~h}$ as described above.

\section{Pancreatic islet isolation and culture}

Islets were isolated by collagenase digestion as described previously (Bordin et al. 1995). All the experiments involving animals were performed in accordance with the guidelines of the Brazilian College for Animal Experimentation (COBEA). After isolation, groups of $c a .400$ islets were extensively and carefully washed with KBB containing antibiotics, and were cultured for $24 \mathrm{~h}$. In order to induce apoptosis, pancreatic islets were cultured with PA in RPMI-1640 medium containing $11.1 \mathrm{mM}$ glucose, $10 \% \mathrm{FBS}$, and $2 \%$ of fatty acid-free BSA as described previously (Shimabukuro et al. 1998). Total (bound + unbound) PA concentration used was $1 \mathrm{mM}$, and IL6 concentration was $100 \mathrm{ng} / \mathrm{ml}$. Treatments with PA and/or IL6 were performed for $24 \mathrm{~h}$. After culture, groups of $\sim 250$ islets grown under each condition were processed for protein extraction and western blotting or for the detection of DNA fragmentation. For DNA fragmentation, groups of 50 islets were dissociated by re-suspension in $\mathrm{Ca}^{2+}$-free KBB containing EDTA.

\section{Caspase-3 activity}

Cells were seeded in six-well plates $\left(5 \times 10^{5} /\right.$ well $)$, and treated as described in the figure legends. Afterwards, the cells were centrifuged at $1000 \boldsymbol{g}$ for $15 \mathrm{~min}$ at $4{ }^{\circ} \mathrm{C}$, and $200 \mu \mathrm{l}$ of a lysis buffer containing $10 \%$ sucrose, $0 \cdot 1 \%$ CHAPS, $100 \mathrm{mM}$ HEPES, pH 7•4, $10 \mathrm{mg} / \mathrm{ml}$ leupeptin, $10 \mathrm{mg} / \mathrm{ml}$ aprotinin, $2 \mathrm{mM}$ phenylmethylsulphonyl fluoride (PMSF), and $10 \mathrm{mM}$ dithiothreitol (DTT) were added to the pellet. The cells were incubated for $30 \mathrm{~min}$ at $4{ }^{\circ} \mathrm{C}$ and centrifuged at $12000 \mathrm{~g}$ for $30 \mathrm{~min}$ at $4{ }^{\circ} \mathrm{C}$. The supernatant was collected, and the protein content was determined by the Bradford method. Caspase- 3 protease activity was determined by incubating the lysate (20 $\mu \mathrm{g}$ of total protein) with $50 \mathrm{mM}$ fluorogenic substrate Ac-DEVD-AMC (Sigma) in a buffer containing 10\% sucrose, $100 \mathrm{mM}$ HEPES, pH 7•4, $10 \mathrm{mg} / \mathrm{ml}$ leupeptin, $10 \mathrm{mg} / \mathrm{ml}$ 
aprotinin, $200 \mathrm{mM}$ PMSF, and $10 \mathrm{mM}$ DTT. Caspase-3 activity was assessed by measuring the fluorescence of Asp-7amino-4-trifluoromethyl coumarin released at 30 min during the 5-min intervals using a spectrofluorometer (Molecular Devices Spectra MAX Gemini XS, Sunnyvale, CA, USA).

\section{Determination of membrane integrity and DNA fragmentation}

Cells were seeded in six-well plates $\left(5 \times 10^{5} /\right.$ well), and were treated as described in the figure legends. Afterwards, the cells were harvested with trypsin, washed, and suspended in PBS. Cell suspensions were divided into two aliquots, and were used to determine DNA fragmentation and membrane integrity. Both the methodologies were based on propidium iodide (PI) staining and fluorescence, which was measured using a flow cytometer. First, $50 \mu \mathrm{l}$ of isotonic solution containing PI $(50 \mathrm{mg} / \mathrm{ml}$ in PBS) were used to homogenize one pelleted aliquot from each sample, and were immediately analyzed using a FACSCalibur flow cytometer (Becton Dickinson, San Juan, PR, USA). PI is highly hydrosoluble and usually does not significantly diffuse into the cell. However, when membrane integrity is disrupted, it does occur, making the cell emit fluorescence when excited by the laser. Fluorescence was measured using the FL2 channel (orange-red fluorescence; 585/42 nm). Ten thousand events were analyzed per sample using the CellQuest software (Becton Dickinson). DNA fragmentation was measured by staining the second aliquot of the cell suspension obtained from each sample with a PI solution according to the method described previously (Verlengia et al. 2003). In this case, the cells were incubated for $1 \mathrm{~h}$ at room temperature (RT) with a PI solution containing $0 \cdot 1 \%$ Triton X-100 $(50 \mathrm{mg} / \mathrm{ml}$ PI, $0 \cdot 1 \%$ sodium citrate, and $0 \cdot 1 \%$ Triton $\mathrm{X}-100)$. The presence of the detergent in the solution makes the cell membrane permeable to PI, allowing it to be incorporated into cellular DNA. Fluorescence was measured and analyzed using the CellQuest software, and low fluorescence was emitted by fragmented DNA, while intact haploid and diploid DNAs emitted characteristic two-peaked high-intensity fluorescence.

\section{RINm $5 F$ cell proliferation}

Cell proliferation was assessed by measuring bromodeoxyuridine (BrdU) incorporation into DNA using a commercial kit (Millipore, Billerica, MA, USA; Cat. no. 2750). Briefly, $4 \times 10^{4}$ cells were seeded in a 96-well plate, and were allowed to attach to the wells containing the growth medium overnight. On the next day, the medium was replaced with low serum medium $(0 \cdot 1 \% \mathrm{FBS})$, in which each treatment was carried out. Cytokine mixture, PA and IL6 concentrations and incubation periods were exactly the same as those used for apoptosis assays. BrdU stock solution (provided with the kit) was diluted $500 \times$ and added to the medium $4 \mathrm{~h}$ before the end of the treatments. One well maintained under each condition was kept without $\operatorname{BrdU}$ to be used as the background (BG). After incubation, the medium was removed, and a fixing solution was added to the adhered cells for $30 \mathrm{~min}$ at RT. The fixing solution was removed, and the cells were washed three times with $1 \times$ washing solution. Next, the cells were incubated for $1 \mathrm{~h}$ at RT with anti-BrdU antibody diluted $200 \times$ in antibody diluents. Cells were washed three times and were then incubated with goat antimouse IgG antibody conjugated with peroxidase for $30 \mathrm{~min}$ at RT. Afterwards, the cells were washed and incubated with 3,3',5,5'-tetramethylbenzidine sulfate (TMB) peroxidase substrate for $30 \mathrm{~min}$ at RT in the dark, and then a stop solution was added. Using a spectrophotometer, 450-nm light absorbance was acquired. Blanks (TMB peroxidase substrate plus the stop solution) were discounted from all the readings, and the respective BG absorbance was discounted from each condition.

\section{RNA extraction and RT-PCR}

Cells were harvested in TRIzol, and were processed for total RNA extraction and cDNA synthesis, which were performed using conventional (GoTaq DNA Polymerase, Promega) or real-time (SYBR Green master mix, Applied Biosystems, Foster City, CA, USA) PCR. The sequences of the primers and amplification conditions were as follows: B-cell CLL/lymphoma (Bcl2; NM_016993) sense 5'-GCAGAGATGTCCAGTCAGC- $3^{\prime}$ and antisense $5^{\prime}$-CCCACCGAACTCAAAGAAGG-3', $128 \mathrm{bp}, 55^{\circ} \mathrm{C}$; $\mathrm{Bcl} 2$ associated $\mathrm{X}$ protein (Bax; NM_017059) sense $5^{\prime}$-GGAGATGAACTGGACAATAATATGG-3' and antisense $5^{\prime}$-GCAAAGTAGAAGAGGGCAACC-3 ${ }^{\prime}, 151$ bp, $53^{\circ} \mathrm{C} ; \beta 2$-microglobulin ( $\beta 2 M$; NM_012512) sense 5'-CTCAGTTCCACCCACCTCAG-3' and antisense $5^{\prime}$-GCAAGCATATACATCGGTCTC-3', $157 \mathrm{bp}, 56^{\circ} \mathrm{C}$; succinate dehydrogenase subunit A (Sdha; NM_130428) sense 5'-CGGAAGCACGGAAGGAGTC- $3^{\prime}$ and antisense 5'-CAGTAGGAACGGATAGCAGGAG-3', $249 \mathrm{bp}, 56^{\circ} \mathrm{C}$. Relative expression levels were analyzed using the $2(-\Delta \Delta C(\mathrm{~T}))$ method (Livak \& Schmittgen 2001) with $\beta 2 m$ and $S d h a$ as the internal controls. Conventional RT-PCR was performed for the analysis of $\mathrm{X}$-box binding protein gene $(X b p 1)$ splicing as described previously (Kharroubi et al. 2004). Briefly, PCR products were incubated with the PstI restriction enzyme for $5 \mathrm{~h}$ at $37{ }^{\circ} \mathrm{C}$, followed by separation on a $2 \% \mathrm{EtBr}$ agarose gel. Primer sequences and amplification conditions were as follows: Xbp1 (NM_001004210) sense 5'-AAACAGAGTAGCAGCGCAGACTGC-3' and antisense $5^{\prime}$-GGATCTCTAAAACTAGAGGCTTGGTG-3', 600 bp, $52^{\circ} \mathrm{C}$.

\section{Western blotting}

Cells were harvested in a lysis buffer and homogenized by sonication. After centrifugation, equal amounts of protein were resolved by SDS-PAGE, and transferred onto nitrocellulose membranes. Detection using specific antibodies, HRP-conjugated secondary antibodies, and luminol solution was performed as described previously (Anhê et al. 2006). 
Anti-BCL2 (sc492), anti-signal transducer and activator of transcription 3 (STAT3) (sc483), anti-phospho-STAT3 Tyr (sc8059), anti-CHOP (sc575 and sc793), anti-phosphoAKT1/2/3 Ser (sc33437), anti-tribble3 (TRIB3) (sc34212), and anti-activating transcription factor 4 (ATF4) (sc200) antibodies were obtained from Santa Cruz Technology. Anti-BAX (B3428) and anti- $\beta$-actin (A5316) antibodies were obtained from Sigma; anti-AKT1 (05-796) was obtained from Upstate Biotechnology (Waltham, MA, USA); and antiphospho-pancreatic eukaryotic initiation factor- $2 \alpha$ kinase (PERK) Thr980 (3179) and anti-immunoglobulin heavy chain-binding protein (BiP) (3183) antibodies were obtained from Cell Signaling Technology (Beverly, MA, USA). Densitometry was performed using the Scion Image software (Scion Corporation, Frederick, MD).

\section{Statistical analysis}

Results are presented as means \pm S.E.M. Comparisons were performed using one-way ANOVA with the Tukey-Kramer post-test (InStat - GraphPad Software, Inc., San Diego, CA, USA). The level of significance was set at $P<0 \cdot 05$.

\section{Results}

IL6 modulation of STAT3 and AKT phosphorylation and pro-inflammatory cytokine-induced apoptosis and suppression of proliferation

We have demonstrated the activation of proteins downstream of the IL6 receptor, namely STAT3 and protein kinase B/AKT. The phosphorylation of both STAT3-tyrosine and AKTserine peaked at $15 \mathrm{~min}$ after incubation with IL6 (Fig. 1A). The concentration of IL6 used in the further experiments was also assessed. IL6 at $100 \mathrm{ng} / \mathrm{ml}$ produced a significant increase in the phosphorylation of both STAT3 and AKT (Fig. 1B). Figure 1C shows that CM-treated cells displayed higher DNA fragmentation $(2 \cdot 3$-fold of the CTL values) which was abolished by pre-treatment with IL6. These changes paralleled the modulation of caspase- 3 activity. Figure 1D shows that CM increased caspase- 3 activity (10.8-fold of the CTL values) and IL6 diminished CM-induced caspase-3 activation (0.36-fold compared with the CM-treated cells). Cell viability was not significantly changed by CM treatment (Fig. 1E). In contrast, Fig. 1F shows that both IL6 and CM decreased cell proliferation (to $0 \cdot 85$ - and to $0 \cdot 56$-fold of the CTL values respectively). Additionally, the combination of $\mathrm{CM}$ and IL6 prompted a more pronounced reduction in cell proliferation $(0 \cdot 03$-fold of the CTL values).

Effects of IL6 on PA-induced cell death and proliferation, and STAT3 and AKT phosphorylation

The percentage of RINm5F cells with fragmented DNA increased approximately fourfold on PA treatment (Fig. 2A). Concordantly, PA treatment of RINm5F cells increased
A

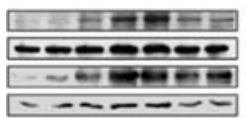

IL6

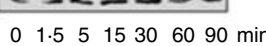

B

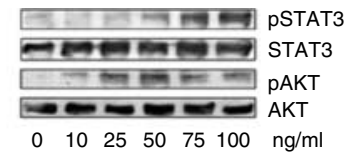

C

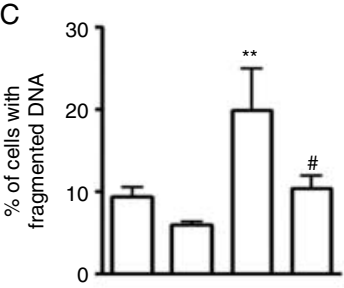

D
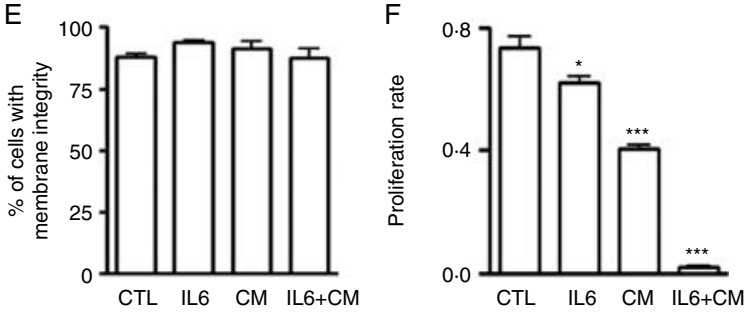

Figure 1 IL6-induced AKT and STAT3 phosphorylation and protection against apoptosis elicited by pro-inflammatory cytokines in RINm5F cells. RINm5F cells were stimulated with IL6 $(100 \mathrm{ng} / \mathrm{ml})$ for $1.5,5,15,30,60$, and $90 \mathrm{~min}$ (A). Cells were also incubated for 30 min with IL6 at the final concentrations of 10, 25, 50,75 , and $100 \mathrm{ng} / \mathrm{ml}$ (B). Afterwards, the cells were processed for protein extraction and detection of STAT3, pSTAT3(Tyr), AKT, and pAKT(Ser) $(n=3)$. RINm5F cells were treated with IL6 $(100 \mathrm{ng} / \mathrm{ml})$ in combination with or without a mixture of IL1 $\beta(4 \cdot 4 \mathrm{ng} / \mathrm{ml})$, IFN- $\gamma$ $(10 \cdot 3 \mathrm{ng} / \mathrm{ml})$, and TNF- $\alpha(4 \cdot 4 \mathrm{ng} / \mathrm{ml}$; cytokine mixture, CM). Untreated cells are designated as CTL cells. After $24 \mathrm{~h}$, cellular DNA fragmentation (C), caspase-3 activity (D), cell membrane integrity $(\mathrm{E})$, and cell proliferation rate $(\mathrm{F})$ were analyzed (see Materials and Methods). Results are shown as mean \pm s.E.M. ${ }^{*} P<0 \cdot 05,{ }^{*} P<0 \cdot 01$ and ${ }^{* * *} P<0 \cdot 001$ versus $\mathrm{CTL},{ }^{\sharp} P<0.05$ and ${ }^{\&} P<0 \cdot 001$ versus $C M(n=3-6)$.

caspase-3 activity 30-fold when compared with the CTL cells (Fig. 2B). IL6 treatment did not change basal or PA-induced DNA fragmentation and caspase- 3 activation. PA treatment reduced cell viability to $\sim 0 \cdot 8$-fold of the CTL values, and this effect was not modulated by IL6 treatment (Fig. 2C). Figure 2D shows that both IL6 and PA decreased cell proliferation (to $0 \cdot 85$ - and to $0 \cdot 37$-fold of the CTL values respectively). The combination of IL6 and PA did not promote a further reduction in cell proliferation.

On the other hand, IL6 signaling was differentially regulated by PA. The phosphorylation of both STAT3 and AKT was increased by IL6 $(2 \cdot 1$-fold of the CTL values for both STAT3 and AKT), but only IL6-induced AKT phosphorylation was suppressed by PA (Fig. 3).

\section{Regulation of pro- and anti-apoptotic proteins by IL6 and PA}

IL6 by itself increased the expression of the anti-apoptotic $B c l 2$ mRNA (2.7-fold of the CTL values). Bcl2 mRNA 

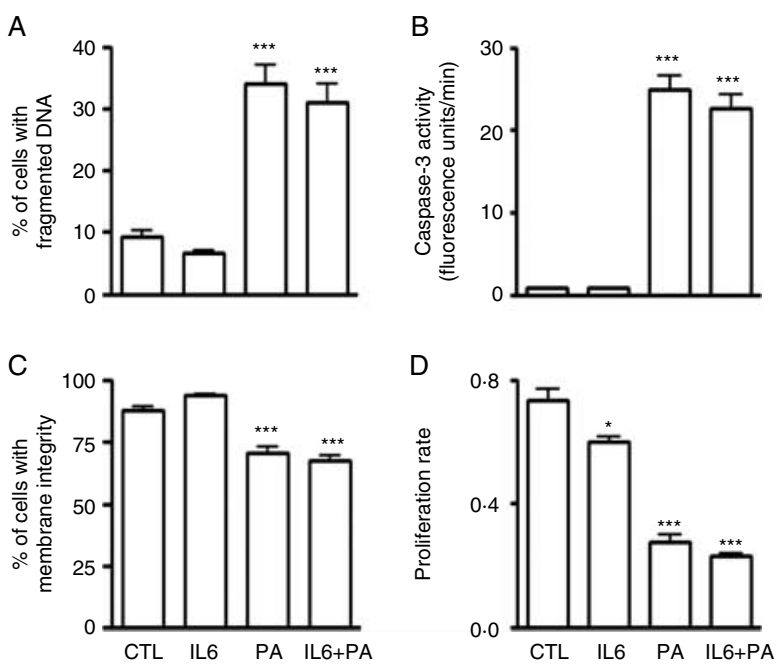

Figure 2 Modulation of apoptosis and cellular viability by palmitate and IL6. RINm5F cells were treated with IL6 $(100 \mathrm{ng} / \mathrm{ml}$ for $36 \mathrm{~h})$. Palmitate $(\mathrm{PA} ; 250 \mu \mathrm{M})$ was added during the last $12 \mathrm{~h}$ of the $36-\mathrm{h}$ period. CTL cells were treated with a vehicle. Next, DNA

fragmentation $(\mathrm{A})$ and cell membrane integrity $(\mathrm{C})$ were analyzed by propidium iodide fluorescence assessed using a flow cytometer. Caspase-3 activity (B) was evaluated by spectrofluorometry, and the proliferation rate (D) was evaluated based on BrdU incorporation. Results are shown as mean \pm s.E.M. ${ }^{*} P<0 \cdot 05$, and ${ }^{* * *} P<0 \cdot 001$ versus CTL and IL6 $(n=6-15)$.

expression was downregulated by PA alone or in combination with IL6 (by 0 5 - and 0.4-fold of the CTL values respectively; Fig. 4A). The absolute levels of BCL2 protein were not altered by either IL6 or PA (Fig. 4B). The levels of the proapoptotic BCL2-associated X protein (Bax) mRNA were downregulated by IL6 $(0 \cdot 3$-fold of the CTL values), and upregulated by PA alone or in combination with IL6 (by $2 \cdot 2-$ and $1 \cdot 8$-fold of the CTL values respectively; Fig. 4C). IL6 decreased BAX protein content $(0 \cdot 6$-fold of the CTL values), but the presence of PA abolished this effect (Fig. 4D). IL6 increased $B c l 2 / B a x$ mRNA ratio (10-fold of the CTL values), whereas PA decreased it $(0 \cdot 3$-fold of the $\mathrm{CTL}$ values). In addition, $\mathrm{Bcl} 2 / \mathrm{Bax} \mathrm{mRNA}$ ratio remained reduced when IL6 was combined with PA (Fig. 4E). BCL2/ BAX protein ratio was increased by IL6 alone $(1 \cdot 8$-fold of the CTL values), but this effect was abolished when PA was added to the medium (Fig. 4F).

\section{Analysis of UPR and TRB3 expression under PA and IL6 treatments}

Representative blots of the effects of IL6 and PA treatments on BiP, ATF4, CHOP, and TRIB3 protein contents are shown in Fig. 5A. Both the appearance of phosphorylated PERK (Fig. 5B) and the splicing of Xbp1 (Fig. 5C) were stimulated by PA, in such a way that the addition of IL6 did not interfere with this upregulation. Neither IL6 nor PA modulated BiP content (Fig. 5D). On the other hand, ATF4 and CHOP contents were increased by PA treatment (1.9and $2 \cdot 2$-fold of the CTL values respectively; Fig. $5 \mathrm{E}$ and $\mathrm{F}$ respectively). Addition of IL6 to the medium did not modulate PA-induced increase in ATF4 and CHOP. PA, either alone or in combination with IL6, did not change eIF2 $\alpha$ phosphorylation (data not shown). We have also shown that the expression of TRIB3 presented a pattern that was the
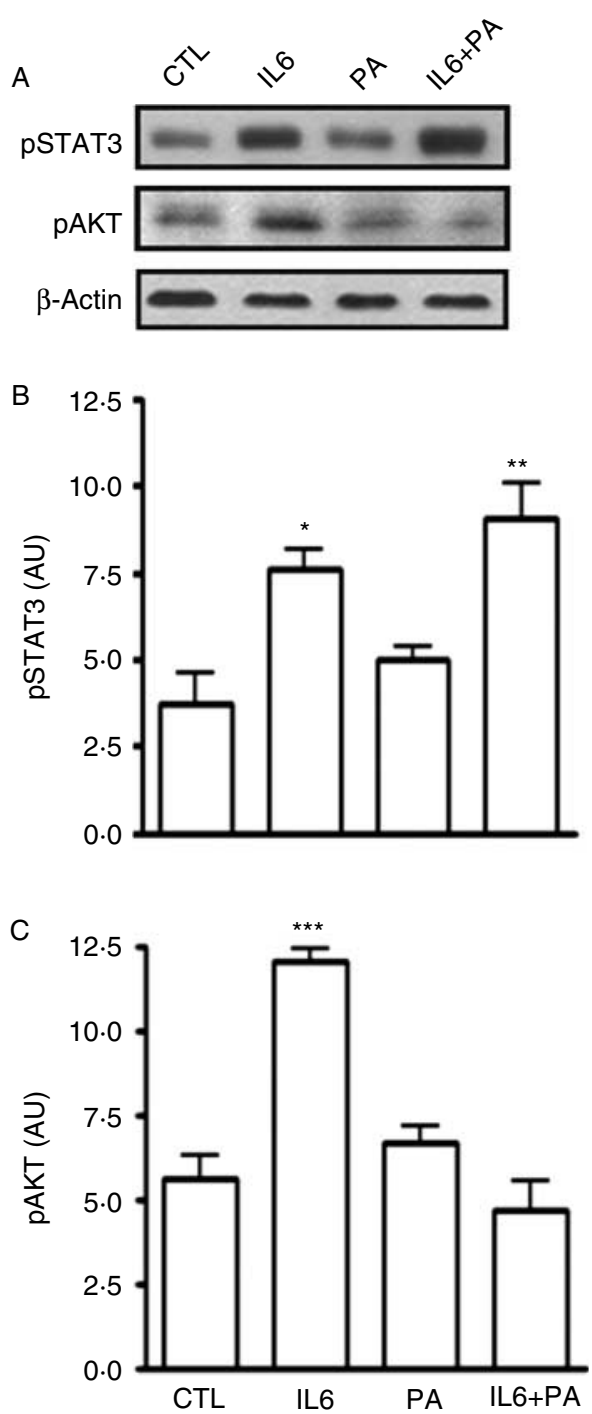

Figure 3 Modulation of STAT3 and AKT phosphorylation by palmitate and IL6. RINm5F cells were treated with IL6 $(100 \mathrm{ng} / \mathrm{ml}$ for $36 \mathrm{~h}$ ). Palmitate (PA; $250 \mu \mathrm{M}$ ) was added during the last $12 \mathrm{~h}$ of the $36-\mathrm{h}$ period. CTL cells were treated with a vehicle. Protein was extracted, resolved by SDS-PAGE and transferred onto nitrocellulose membranes that were probed for the detection of tyrosinephosphorylated STAT3, serine-phosphorylated AKT, and $\beta$-actin (loading control) (A), and the intensity of the bands was analyzed by densitometry using different sets of experiments $(B)$ and (C). Results are shown as mean \pm S.E.M. $* P<0 \cdot 05,{ }^{* *} P<0 \cdot 01$ and *** $P<0 \cdot 001$ versus CTL $(n=3-\overline{7})$. 
A
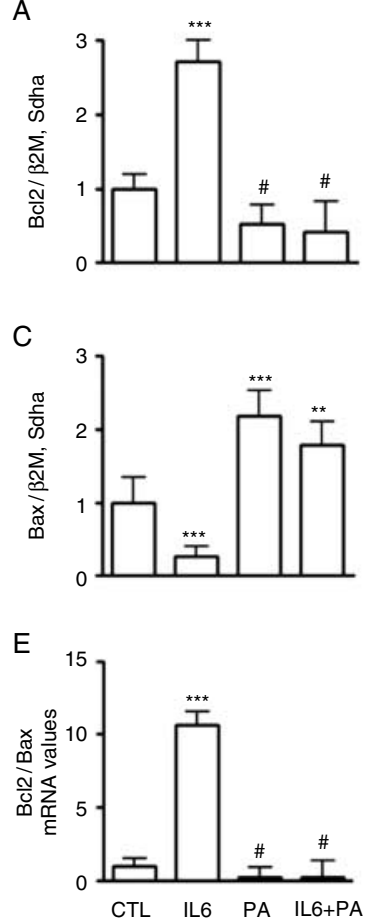
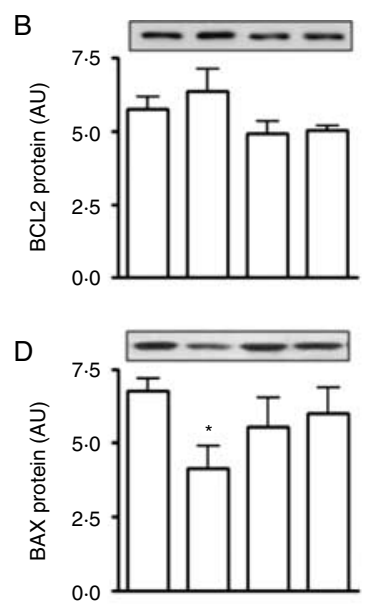

$\mathrm{F}$

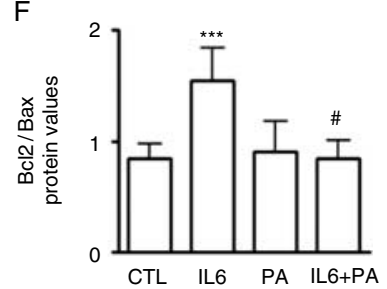

Figure 4 Modulation of BCL2 and BAX expression by palmitate and IL6. RINm5F cells were treated with IL6 $(100 \mathrm{ng} / \mathrm{ml}$ for $36 \mathrm{~h})$. Palmitate (PA; $250 \mu \mathrm{M})$ was added during the last $12 \mathrm{~h}$ of the $36-\mathrm{h}$ period, and the cells were then processed for RNA extraction and CDNA synthesis. CTL cells were treated with a vehicle. Samples were used for real-time PCR analysis of $B C l 2(A)$ and Bax $(C)$. Another set of cells was subjected to the same treatment, and processed for protein extraction and western blot detection of BCL2 (B) and BAX (D). The ratio between Bcl2 and Bax mRNA (E) and $B C L 2$ and $B A X$ protein content were also calculated $(F)$. Results are shown as mean \pm s.E.M. ${ }^{*} P<0 \cdot 05,{ }^{* *} P<0 \cdot 01$ and ${ }^{* * *} P<0 \cdot 001$ versus CTL; ${ }^{\#} P<0 \cdot 001$ versus IL6 $(n=3-6)$.

same as that of ATF4 and CHOP. TRIB3 protein levels were increased by PA treatment $(1 \cdot 8$-fold of the CTL values), and were not affected by the presence of IL6 (Fig. 5G). A profile that was the same as that found for TRIB3 protein expression was detected for Trib3 mRNA expression analyzed by realtime PCR (data not shown).

Modulation of DNA fragmentation and ER stress by IL6 in rat pancreatic islets cultured with $P A$

Our data show that both IL6 and PA increase DNA fragmentation in pancreatic islets cultured for $24 \mathrm{~h}$ (to $\sim 1 \cdot 6$-fold of the CTL values). The combination of PA and IL6 resulted in a further increase in DNA fragmentation (to $2 \cdot 4$-fold of the CTL values; Fig. 6A). Figure 6B shows the representative blots of CHOP and TRIB3 obtained in cultured pancreatic islets. PA increased both CHOP and TRIB3 protein contents in islets to $2 \cdot 4$ - and $3 \cdot 0$-fold of the CTL values respectively. These changes were not modulated by IL6 (Fig. 6C and D respectively).

Analysis of UPR and TRIB3 expression under CM and IL6 treatments

Representative blots of the effects of IL6 and CM treatments on BiP, ATF4, CHOP and TRIB3 protein contents are shown in Fig. 7A. Neither IL6 nor CM modulated BiP content (Fig. 7B). CM induced a 1.6-fold increase in ATF4 content, which was suppressed by the presence of IL6 (Fig. 7C). In addition, CHOP (Fig. 7D) and TRIB3 (Fig. 7E) contents were not changed by CM and/or IL6 treatment.

\section{CHOP knockdown with siRNA suppresses $P A$-induced apoptosis in RINm5F cells}

As shown previously herein, PA induced an increase in DNA fragmentation in RINm5F cells (Fig. 8B). Specific knockdown of CHOP with siRNA (Fig. 8A) had no effect on basal DNA fragmentation, but it abolished the ability of PA to increase it. DNA fragmentation that was induced by PA in
A
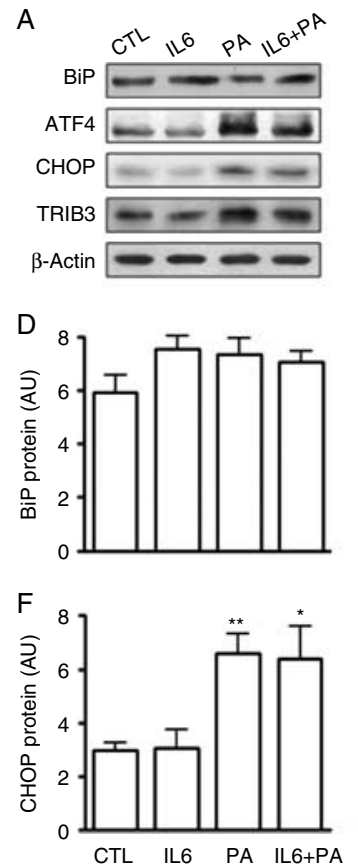
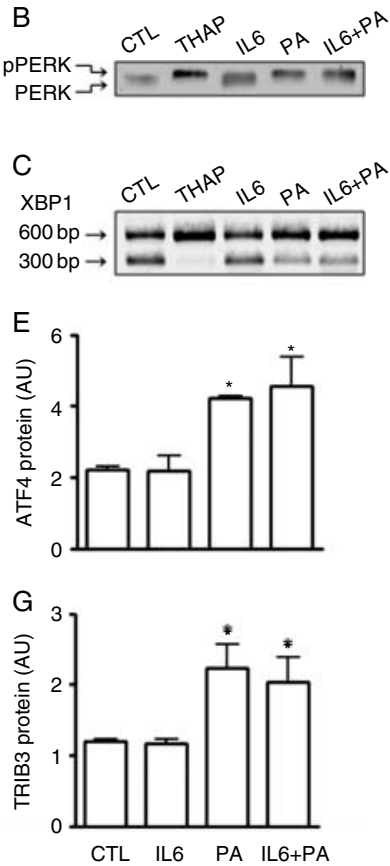

Figure 5 Modulation of UPR-related proteins by PA and IL6. RINm5F cells were treated with IL6 (100 ng/ml for $36 \mathrm{~h})$. Palmitate $(\mathrm{PA} ; 250 \mu \mathrm{M}$ ) was added during the last $12 \mathrm{~h}$ of the 36 -h period. CTL cells were treated with a vehicle. Next, the cells were processed for protein extraction and western blot detection of BiP, ATF4, CHOP, TRIB3, and $\beta$-actin (A). For phosphorylated PERK detection, an additional sample of RINm5F cells treated with thapsigargin $(1 \mu \mathrm{M}$ for $12 \mathrm{~h}$; THAP) was used as a positive CTL (B). Another set of cells was subjected to the same treatment, and processed for RNA extraction and cDNA synthesis. Samples were used for Xbp1 amplification followed by analysis of alternative splicing using PstI digestion $(\mathrm{C})$. The intensity of the bands of BiP (D), ATF4 (E), CHOP $(\mathrm{F})$, and TRIB3 $(\mathrm{G})$ was analyzed by densitometry using different sets of experiments. Results are shown as mean \pm S.E.M. ${ }^{*} P<0 \cdot 05$ and $* * P<0 \cdot 01$ versus CTL and IL6 $(n=6-9)$. 


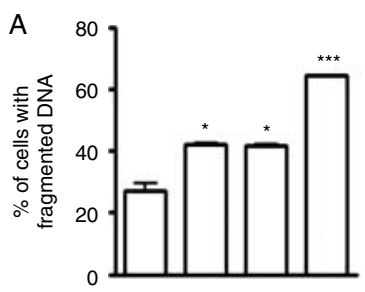

B

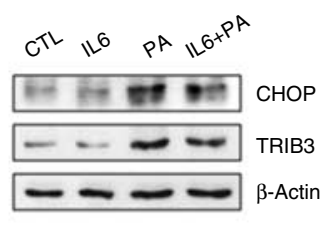

C

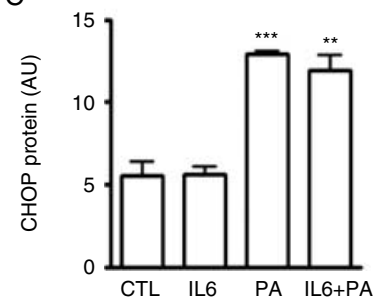

D

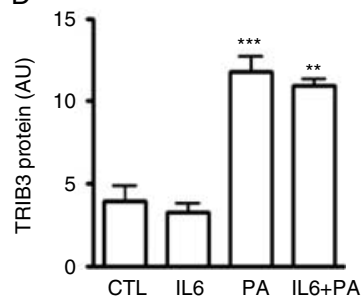

Figure 6 Effects of palmitate and IL6 on apoptosis and UPR-related proteins in pancreatic rat islets. Isolated rat islets were treated with IL6 $(100 \mathrm{ng} / \mathrm{ml})$ and palmitate $(\mathrm{PA} ; 1 \mathrm{mM})$ for $24 \mathrm{~h}$, and processed for the analysis of DNA fragmentation by propidium iodide fluorescence (A) and western blotting. In (B), the representative film image of CHOP, TRIB3, and $\beta$-actin (loading control) is shown. In (C) and (D), the mean \pm s.E.M. of CHOP and TRIB3 protein contents that were obtained from two to three independent experiments and analyzed by densitometry is shown. ${ }^{*} P<0 \cdot 05$ versus $C T L$; and ${ }^{* *} P<0.01$ and ${ }^{* * *} P<0.001$ versus CTL and IL6 $(n=6-18$ for DNA fragmentation analysis).

RINm5F cells transfected with siRNA targeted at CHOP was $0 \cdot 7$-fold of that induced by PA in untransfected cells, reaching values similar to the CTL values $(1 \cdot 1$-fold).

\section{Discussion}

IL6 has been suggested to protect pancreatic $\beta$-cells from apoptosis induced by TNF- $\alpha$, IFN- $\gamma$, and IL- $1 \beta$, which are the main pro-inflammatory cytokines involved in the assault of the endocrine pancreas during the onset of T1DM (Park et al. 2003, Choi et al. 2004). Moreover, mating of mice that overexpress IL6 with NOD mice decreased the incidence of diabetes (DiCosmo et al. 1994). On the other hand, IL6 was reported to decrease insulin secretion and $\beta$-cell proliferation (Sandler et al. 1990). These observations show that the role of IL6 in $\beta$-cell survival and function is complex, and justify additional studies in order to clarify the intracellular mechanisms and cellular responses elicited by this cytokine in pancreatic $\beta$-cells. To further address this issue, we sought to investigate if IL6 protects $\beta$-cell against lipotoxicity induced by FFAs.

Our study has demonstrated that IL6 activates its classical target STAT3 in RINm5F cells. AKT pathway, a noncanonical signaling pathway of IL6 (Hsu et al. 2004), was also activated in RINm5F cells. IL6 by itself enhanced $\mathrm{Bcl} 2$ expression and decreased Bax expression, probably as a result of STAT3 activation (Kovalovich et al. 2001). Inhibition of the mitochondrial pathway of apoptosis by adipokines has been documented already and is in agreement with our results. Leptin, which shares intracellular signaling pathways with IL6, increases BCL2 and decreases BAX, altering the BCL2:BAX ratio and reducing apoptosis induced by serum depletion in BRIN-BD11 $\beta$-cell line (Brown \& Dunmore 2007). Furthermore, we observed that IL6 decreased apoptosis induced by pro-inflammatory cytokines. Altogether, our results confirm that IL6 protects RINm5F cells against pro-inflammatory cytokine-induced apoptosis, as has been published already by others (Park et al. 2003, Choi et al. 2004). In contrast, we have shown that IL6 potentiates the reduction of pancreatic $\beta$-cell proliferation induced by pro-inflammatory cytokines. We currently have no data to explain this finding. A hypothesis is that IL6 promotes the growth arrest of RINm5F cells, as it does in other cell types (Kamimura et al. 2003). Of note, our experiments were carried out for a short period during which IL6 treatment was given, which was described to decrease islet DNA content (Sandler et al. 1990).
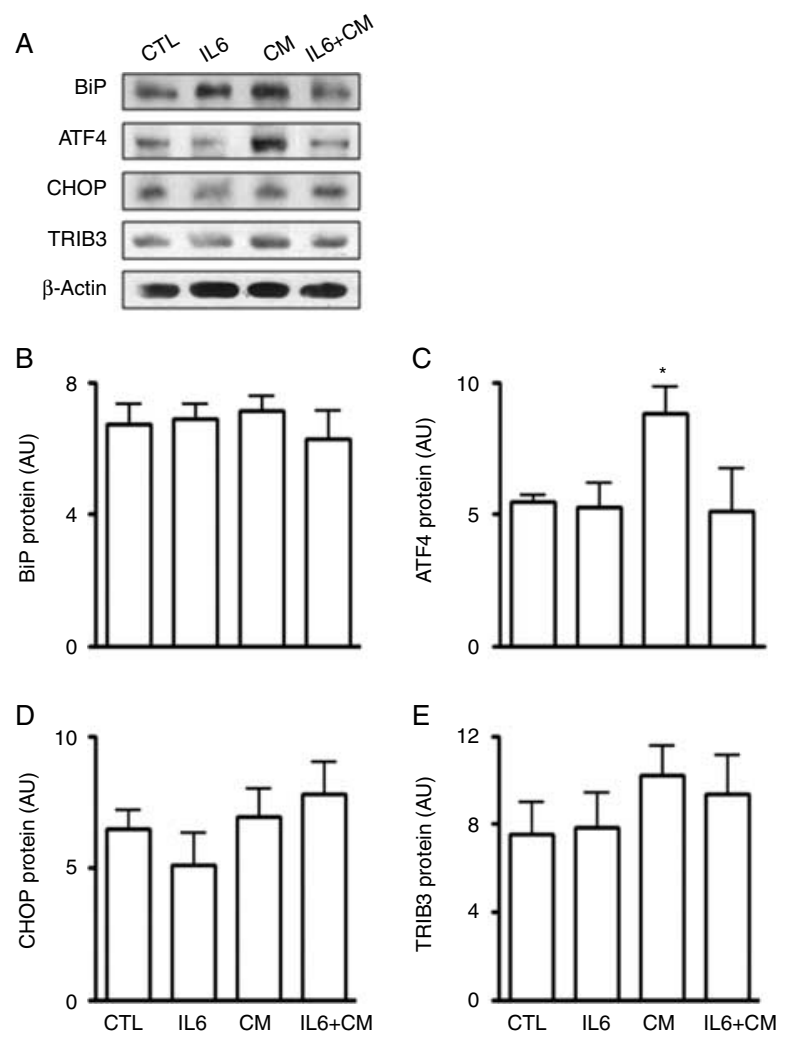

Figure 7 Modulation of UPR-related proteins by cytokines mixture and IL6. RINm5F cells were treated with IL6 $(100 \mathrm{ng} / \mathrm{ml})$ in combination with or without a mixture of IL1 $\beta(4 \cdot 4 \mathrm{ng} / \mathrm{ml})$, IFN- $\gamma$ $(10 \cdot 3 \mathrm{ng} / \mathrm{ml})$, and TNF $\alpha(4 \cdot 4 \mathrm{ng} / \mathrm{ml}$; cytokine mixture, CM). CTL cells were treated with a vehicle. After $24 \mathrm{~h}$, the cells were processed for protein extraction and western blot detection of $\mathrm{BiP}$, ATF4, CHOP, TRIB3, and the internal control $\beta$-actin (A). The intensity of the bands of BiP (B), ATF4 (C), CHOP (D), and TRIB3 (E) was analyzed by densitometry using different sets of experiments. Results are shown as mean \pm S.E.M. ${ }^{*} P<0 \cdot 05$ versus CTL $(n=4-8)$. 

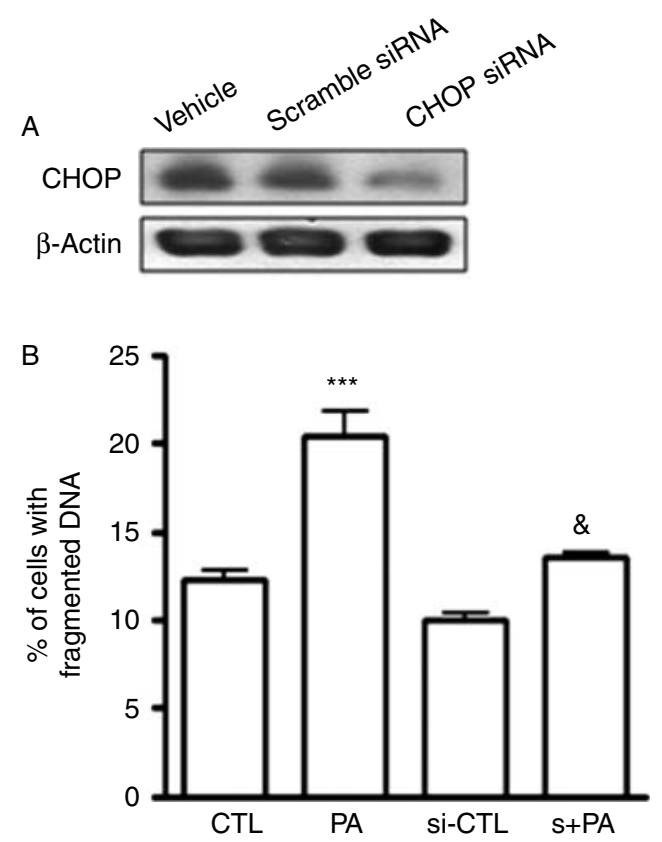

Figure 8 Effect of palmitate on DNA fragmentation after knockdown of CHOP with siRNA. RINm5F cells were transfected with small interfering RNA targeted at $\mathrm{CHOP}$ (CHOP siRNA) or with a scrambled control siRNA (scrambled siRNA). Lipofectamine 2000 was mixed with siRNAs and used in the CTL experiment. Palmitate (PA; $250 \mu \mathrm{M}$ ) was added during the last $12 \mathrm{~h}$ of the $72-\mathrm{h}$ period after the transfection; after that, the cells were processed for total protein extraction and SDS-PAGE. Samples from CTL, scrambled siRNA, and $\mathrm{CHOP}$ siRNA cells were subjected to immunodetection of $\mathrm{CHOP}$ and $\beta$-actin, the latter being used to check the specificity of CHOP siRNA (A). DNA fragmentation was analyzed by propidium iodide fluorescence assessed using a flow cytometer (B).

${ }^{* * *} P<0 \cdot 001$ versus $C T L$ and ${ }^{\&} P<0 \cdot 001$ versus $P A(n=7-15)$.

Pancreatic $\beta$-cell death occurs in both T1DM and T2DM, but in opposition to that in T1DM, $\beta$-cell apoptosis in T2DM is likely to result mainly from lipotoxicity and glucotoxicity. PA, are of the most abundant FFAs found in serum (Hamilton \& Kamp 1999), is known as a potent inductor of $\beta$-cell apoptosis in primary $\beta$-cells and RINm5F cells (Beeharry et al. 2004, Azevedo-Martins et al. 2006). Our results show that IL6 did not protect RINm5F cells from PA-induced apoptosis. This finding is supported by clinical observations showing that obese and insulin-resistant patients often develop T2DM regardless of increased IL6 circulating levels (Herder et al. 2006).

In contrast to that observed in $\beta$-cell lineage, our results show that IL6 potentiated PA-induced apoptosis in cells obtained from cultured islets. Ellingsgaard et al. (2008) found similar results using cultured mouse islets. We do not have any explanation for this, but we can speculate that the release of cytotoxic mediators by the variety of resident cell types in islets, that is, macrophages, endothelial cells, and endocrine cells, could play a detrimental role in islet survival. Of note, collagenase-isolated islets have higher apoptotic rate than $\beta$-cell lineages, probably due, at least in part, to the release of pro-inflammatory cytokines induced by endotoxin contamination of the conventional type $\mathrm{V}$ collagenase (Berney et al. 2001). Indeed, several reports have shown that IL6 alone is not cytotoxic to $\beta$-cells (reviewed by Kristiansen \& Mandrup-Poulsen (2005)). However, phenotypic differences between primary $\beta$-cells and clonal $\beta$-cell lines cannot be ruled out.

The mechanism underlying the inability of IL6 to protect RINm5F cells against PA-induced apoptosis probably relies on the disruption of IL6 signaling pathways. We have found that phosphorylation of both STAT3 and AKT was activated by IL6, but only that of AKT was impaired by PA. In pancreatic $\beta$-cells, downregulation of STAT3 activity is mainly involved in the modulation of insulin secretion (Gorogawa et al. 2004, Anhê et al. 2007). On the other hand, it is well documented that the phosphatidylinositol 3-kinase (PI3K)/AKT signaling is a critical pathway regulating $\beta$-cell survival (Elghazi et al. 2007), which is impaired by FFAs (Wrede et al. 2002, Kharroubi et al. 2004). Downstream to AKT activation, a myriad of pro-apoptotic proteins can be phosphorylated and inhibited, such as BCL2 family members, GSK3, and FoxO1, resulting in a relief from apoptosis (Datta et al. 1999, Wrede et al. 2002, Martinez et al. 2008). Importantly, overexpression of a constitutively active AKT prevented FFA-induced apoptosis (Wrede et al. 2002).

ER stress-activated UPR has been shown to occur in pancreatic islets obtained from diabetic obese animals and human patients with T2DM (Laybutt et al. 2007). Excess of saturated FFAs can directly trigger ER stress and UPRmediated apoptosis in the pancreatic $\beta$-cell-derived lineages MIN6 (Laybutt et al. 2007) and INS1 (Karaskov et al. 2006) and primary rat pancreatic $\beta$-cells (Kharroubi et al. 2004). Here, we have shown that UPR was activated in RINm5F cells by PA after $12-\mathrm{h}$ incubation $(250 \mu \mathrm{M})$, i.e. in a shorter period and at a lower dose than those required for MIN6 and INS1. Therefore, RINm5F cells are likely to be more sensitive to PA-induced ER stress, in spite of there being no change in BiP expression and eIF2 $\alpha$ phosphorylation. These later effects were not unexpected, since it has been previously demonstrated that, in INS1 cells, BiP levels are not affected by PA (Karaskov et al. 2006, Diakogiannaki et al. 2008). Moreover, eIF2 $\alpha$ phosphorylation is likely to be transient, returning to basal levels after $6-16 \mathrm{~h}$ of treatment. Our results confirm that UPR is far from being an all-or-nothing response, and that it is differentially activated according to the cell type and the stressor.

UPR consists of three branches of signaling pathways that initially aim to adjust the increased ER demand. Activation of UPR is triggered by the dissociation of the chaperone BiP from the transducer proteins PERK, ATF6, and IRE1. BiP dissociation from PERK results in its activation that leads to eIF $2 \alpha$ phosphorylation and ATF4 expression. This initial pathway inhibits general translation rate, and therefore, decreases the flux of new synthesized proteins to the ER (Harding \& Ron 2002). Thus, disruption of the 
PERK/eIF2 $\alpha /$ ATF4 pathway results in the inability of pancreatic $\beta$-cells to deal with increased folding demand, and therefore, accelerates ER stress-mediated apoptosis (Yamaguchi et al. 2008). In spite of the protective feature of this UPR branch, PA has been shown to stimulate the PERK/eIF2 $\alpha /$ ATF4 pathway prior to the induction of pancreatic $\beta$-cell death (Kharroubi et al. 2004). Herein, we have shown that the lack of IL6 protection against PA-induced $\beta$-cell apoptosis correlates with the inability of this IL to prevent PERK phosphorylation and ATF4 expression induced by PA, reinforcing the idea that UPR might mediate lipotoxicity in RINm5F cells.

Similarly, IL6 did not modulate PA-induced increase in $X b p 1$ mRNA splicing. Splicing of Xbp1 mRNA is catalyzed by IRE1a under conditions of ER disturbance. Spliced mRNA of $X b p 1$ encodes for an active transcription factor that facilitates the expression of genes involved in the ER protein degradation (Harding \& Ron 2002). The spliced mRNA of $X b p 1$ has been shown to be increased in the pancreatic islets obtained from diabetic mice, and in the pancreatic islets treated with PA or inflammatory cytokines (Karaskov et al. 2006, Akerfeldt et al. 2008).

We and others have demonstrated that PA increases CHOP expression in pancreatic $\beta$-cells (Wang et al. 2005, Karaskov et al. 2006, Laybutt et al. 2007, Martinez et al. 2008). CHOP is regulated by ATF4, and plays an essential role in the UPRmediated apoptosis in pancreatic $\beta$-cells (Pirot et al. 2007) in such a way that CHOP deletion improves pancreatic $\beta$-cell function in diabetic rodents (Song et al. 2008). As observed for ATF4, IL6 was not able to modulate the increase in CHOP induced by PA. The participation of CHOP in the induction of apoptosis is not completely understood, but one hypothesis is that this transcription factor may suppress $B c l 2$ expression (McCullough et al. 2001). In accordance with ATF4 and $\mathrm{CHOP}$ results, the decrease in $\mathrm{Bcl} 2$ expression induced by PA was not changed by IL6. Reinforcing the role of CHOP in FFA-induced apoptosis, we have shown that siRNAmediated knockdown of CHOP abolishes PA-induced apoptosis in RINm5F cells. This result matches the data that have been published already by performing similar experiments using INS-1 cells (Akerfeldt et al. 2008).

Another important mechanism by which CHOP links ER stress to apoptosis is the induction of TRIB3 expression after dimerization with ATF4 (Ohoka et al. 2005). Herein, we have shown that PA increases TRIB3 content irrespective of the presence of IL6. As TRIB3 has been described to function as a pseudokinase that inhibits AKT (Du et al. 2003), it is likely that PA-induced TRIB3 expression inhibits AKT-serine phosphorylation stimulated by IL6. In accordance with our results, both $\mathrm{PA}$ and high glucose concentrations can trigger UPR-dependent apoptosis in pancreatic $\beta$-cells and concomitantly increase TRIB3 expression (Martinez et al. 2008, Qian et al. 2008).

Our results further suggest that the modulation of the BCL2:BAX ratio by PA in RINm5F cells is possibly linked to the activation of ER stress. This can be hypothesized because i) CHOP was demonstrated to downregulate BCL2 expression (McCullough et al. 2001), and ii) reduced AKT activation might allow the transcription factor FoxO1 to translocate to the nucleus and to induce BAX expression (Kim et al. 2005). In the latter mechanism, ER stress can disrupt AKT activation by inducing TRIB3 expression. In accordance with these two mechanisms, our results show concordant suppression of IL6-induced Bcl2 expression and increase in CHOP by PA. We have also shown that PA sustains high levels of Bax expression in parallel to increased TRIB3, and decreases AKT activity.

Akerfeldt et al. have demonstrated that although proinflammatory ILs are able to induce ER stress and activate UPR, this mechanism is not required for the pro-apoptotic action of these cytokines. On the other hand, these authors suggested that the activation of UPR is a determinant event that culminates in the apoptosis induced by PA (Akerfeldt et al. 2008). Considering these observations, our data suggest that IL6 does not prevent or abolish the disturbance in ER homeostasis elicited by PA, and thus it is not able to protect pancreatic $\beta$-cells from apoptosis induced by elevated FFAs. In contrast, as we and others have demonstrated, IL6 can properly protect $\beta$-cells against pro-inflammatory-induced apoptosis probably because in this case it has been consistently demonstrated that ER stress does not mediate cell death.

Corroborating this hypothesis, we have shown that the combination of pro-inflammatory cytokines used by us efficiently increases DNA fragmentation and caspase-3 activity without increasing BiP, TRIB3, and CHOP, which are proteins that link ER stress to apoptosis in pancreatic $\beta$-cells. In contrast, Akerfeldt et al. (2008) reported that inflammatory cytokines are able to increase CHOP and BiP expression. One plausible explanation for these differences is that the mixture of inflammatory cytokines used by Akerfeldt contained IFN- $\gamma$ at a concentration that was ten times that of IFN- $\gamma$ that was used by us. In our experimental conditions, the only UPR-related protein that paralleled the increase in apoptosis induced by CM in RINm5F cells was ATF4, which was suppressed by IL6. The exact role of this modulation is not clear so far, since the PERK/eIF2 $\alpha /$ ATF4 pathway seems to be protective rather than pro-apoptotic to pancreatic $\beta$-cells (Yamaguchi et al. 2008).

Taken together, our results show that differently from the pro-inflammatory cytokines that trigger apoptosis, IL6 does not prevent PA-induced $\beta$-cell death. This effect is probably due to the inability of IL6 to repress UPR activation and TRIB3 expression, which may result in the blockage of AKT activation.

\section{Declaration of interest}

The authors declare that there is no conflict of interest that could be perceived as prejudicing the impartiality of the research reported.

Journal of Endocrinology (2010) 206, 183-193 


\section{Funding}

This work was supported by the Brazilian foundations FAPESP, CNPq, and CAPES.

\section{Acknowledgements}

The authors acknowledge José Luiz dos Santos and Luciene Maria Ribeiro for their technical assistance.

\section{References}

Akerfeldt MC, Howes J, Chan JY, Stevens VA, Boubenna N, McGuire HM, King C, Biden TJ \& Laybutt DR 2008 Cytokine-induced beta-cell death is independent of endoplasmic reticulum stress signaling. Diabetes $\mathbf{5 7}$ 3034-3044

Anhê GF, Torrão AS, Nogueira TC, Caperuto LC, Amaral ME, Medina MC, Azevedo-Martins AK, Carpinelli AR, Carvalho CR, Curi R et al. 2006 ERK3 associates with MAP2 and is involved in glucose-induced insulin secretion. Molecular and Cellular Endocrinology 251 33-41.

Anhê GF, Nogueira TC, Nicoletti-Carvalho JE, Lellis-Santos C, Barbosa HC, Cipolla-Neto J, Bosqueiro JR, Boschero AC \& Bordin S 2007 Signal transducer and activator of transcription 3-regulated sarcoendoplasmic reticulum $\mathrm{Ca}^{2+}$-ATPase 2 expression by prolactin and glucocorticoids is involved in the adaptation of insulin secretory response during the peripartum period. Journal of Endocrinology 195 17-27.

Anhê FF, Lellis-Santos C, Leite AR, Hirabara SM, Boschero AC, Curi R, Anhê GF \& Bordin S 2010 Smad5 regulates Akt2 expression and insulininduced glucose uptake in L6 myotubes. Molecular and Cellular Endocrinology $31930-38$.

Azevedo-Martins AK, Monteiro AP, Lima CL, Lenzen S \& Curi R 2006 Fatty acid-induced toxicity and neutral lipid accumulation in insulin-producing RINm5F cells. Toxicology In Vitro 20 1106-1113.

Beeharry N, Chambers JA \& Green IC 2004 Fatty acid protection from palmitic acid-induced apoptosis is lost following PI3-kinase inhibition. Apoptosis 9 599-607.

Berney T, Damaris Molano R, Cattan P, Pileggi A, Vizzardelli C, Oliver R, Ricordi C \& Inverardi L 2001 Endotoxin-mediated delayed islet graft function is associated with increased intra-islet cytokine production and islet cell apoptosis. Transplantation 71 125-132.

Bordin S, Boschero AC, Carneiro EM \& Atwater I 1995 Ionic mechanisms involved in the regulation of insulin secretion by muscarinic agonists. Journal of Membrane Biology 148 177-184.

Brown JEP \& Dunmore SJ 2007 Leptin decreases apoptosis and alters BCL-2:Bax ratio in clonal rodent pancreatic beta-cells. Diabetes/Metabolism Research and Reviews 23 497-502.

Choi SE, Choi KM, Yoon IH, Shin JY, Kim JS, Park WY, Han DJ, Kim SC, Ahn C, Kim JY et al. 2004 IL-6 protects pancreatic islet $\beta$ cells from proinflammatory cytokines-induced cell death and functional impairment in vitro and in vivo. Transplant Immunology 13 43-53.

Cnop M, Welsh N, Jonas JC, Jörns A, Lenzen S \& Eizirik DL 2005 Mechanisms of pancreatic beta-cell death in type 1 and type 2 diabetes: many differences, few similarities. Diabetes 54 S97-S107.

Datta SR, Brunet A \& Greenberg ME 1999 Cellular survival: a play in three Akts. Genes and Development 13 2905-2927.

Diakogiannaki E, Welters HJ \& Morgan NG 2008 Differential regulation of the endoplasmic reticulum stress response in pancreatic b-cells exposed to long-chain saturated and monounsaturated fatty acids. Journal of Endocrinology 197 553-563.

DiCosmo BF, Picarella D \& Flavell RA 1994 Local production of human IL-6 promotes insulitis but retards the onset of insulin-dependent diabetes mellitus in non-obese diabetic mice. International Immunology 6 1829-1837.
Donath MY, Ehses JA, Maedler K, Schumann DM, Ellingsgaard H, Eppler E \& Reinecke M 2005 Mechanisms of beta-cell death in type 2 diabetes. Diabetes $\mathbf{5 4}$ 108-113.

Du K, Herzig S, Kulkarni RN \& Montminy M 2003 TRB3: a tribbles homolog that inhibits Akt/PKB activation by insulin in liver. Science $\mathbf{3 0 0}$ 1574-1577.

Elghazi L, Rachdi L, Weiss AJ, Cras-Méneur C \& Bernal-Mizrachi E 2007 Regulation of beta-cell mass and function by the Akt/protein kinase B signalling pathway. Diabetes, Obesity \& Metabolism 9 147-157.

Ellingsgaard H, Ehses JA, Hammar EB, Van Lommel L, Quintens R, Martens G, Kerr-Conte J, Pattou F, Berney T, Pipeleers D et al. 2008 Interleukin-6 regulates pancreatic alpha-cell mass expansion. PNAS 105 13163-13168.

Glund S \& Krook A 2008 Role of interleukin-6 signalling in glucose and lipid metabolism. Acta Physiologica 192 37-48.

Gorogawa S, Fujitani Y, Kaneto H, Hazama Y, Watada H, Miyamoto Y, Takeda K, Akira S, Magnuson MA, Yamasaki Y et al. 2004 Insulin secretory defects and impaired islet architecture in pancreatic beta-cell-specific

STAT3 knockout mice. Biochemical and Biophysical Research Communications 319 1159-1170.

Hamilton JA \& Kamp F 1999 How are free fatty acids transported in membranes? Is it by proteins or by free diffusion through the lipids? Diabetes 48 2255-2269.

Harding HP \& Ron D 2002 Endoplasmic reticulum stress and the development of diabetes: a review. Diabetes 51 S455-S461.

Herder C, Peltonen M, Koenig W, Kräft I, Müller-Scholze S, Martin S, Lakka T, Ilanne-Parikka P, Eriksson JG, Hämäläinen H et al. 2006 Systemic immune mediators and lifestyle changes in the prevention of type 2 diabetes: results from the Finnish Diabetes Prevention Study. Diabetes 55 2340-2346.

Hsu JH, Shi Y, Frost P, Yan H, Hoang B, Sharma S, Gera J \& Lichtenstein A 2004 Interleukin-6 activates phosphoinositol- $3^{\prime}$ kinase in multiple myeloma tumor cells by signaling through RAS-dependent and, separately, through p85-dependent pathways. Oncogene 23 3368-3375.

Kamimura D, Ishihara K \& Hirano T 2003 IL-6 signal transduction and its physiological roles: the signal orchestration model. Reviews of Physiology, Biochemistry and Pharmacology 149 1-38.

Karaskov E, Scott C, Zhang L, Teodoro T, Ravazzola M \& Volchuk A 2006 Chronic palmitate but not oleate exposure induces endoplasmic reticulum stress, which may contribute to INS-1 pancreatic beta-cell apoptosis. Endocrinology 147 3398-3407.

Kharroubi I, Ladriere L, Cardozo AK, Dogusan Z, Cnop M \& Eizirik DL 2004 Free fatty acids and cytokines induce pancreatic beta-cell apoptosis by different mechanisms: role of nuclear factor-kappaB and endoplasmic reticulum stress. Endocrinology 145 5087-5096.

Kim SJ, Winter K, Nian C, Tsuneoka M, Koda Y \& McIntosh CH 2005 Glucose-dependent insulinotropic polypeptide (GIP) stimulation of pancreatic beta-cell survival is dependent upon phosphatidylinositol 3-kinase $(\mathrm{PI} 3 \mathrm{~K})$ / protein kinase $\mathrm{B}(\mathrm{PKB})$ signaling, inactivation of the forkhead transcription factor Foxo1, and down-regulation of bax expression. Journal of Biological Chemistry 280 22297-22307.

Kovalovich K, Li W, DeAngelis R, Greenbaum LE, Ciliberto G \& Taub R 2001 Interleukin-6 protects against Fas-mediated death by establishing a critical level of anti-apoptotic hepatic proteins FLIP, Bcl-2, and Bcl-xL. Journal of Biological Chemistry 276 26605-26613.

Kristiansen OP \& Mandrup-Poulsen P 2005 Interleukin-6 and diabetes: the good, the bad, or the indifferent? Diabetes 54 S114-S124.

Laybutt DR, Preston AM, Akerfeldt MC, Kench JG, Busch AK, Biankin AV \& Biden TJ 2007 Endoplasmic reticulum stress contributes to beta cell apoptosis in type 2 diabetes. Diabetologia 50 752-763.

Livak KJ \& Schmittgen TD 2001 Analysis of relative gene expression data using real-time quantitative PCR and the $2(-$ Delta Delta $C(T))$ method. Methods 25 402-408.

Martinez SC, Tanabe K, Cras-Méneur C, Abumrad NA, Bernal-Mizrachi E \& Permutt MA 2008 Inhibition of Foxo1 protects pancreatic islet beta-cells against fatty acid and endoplasmic reticulum stress-induced apoptosis. Diabetes $\mathbf{5 7}$ 846-859. 
McCullough KD, Martindale JL, Klotz LO, Aw TY \& Holbrook NJ 2001 Gadd153 sensitizes cells to endoplasmic reticulum stress by down-regulating Bcl-2 and perturbing the cellular redox state. Molecular and Cellular Biology 21 1249-1259.

Mohamed-Ali V, Goodrick S, Rawesh A, Katz DR, Miles JM, Yudkin JS, Klein S \& Coppack SW 1997 Subcutaneous adipose tissue releases interleukin-6, but not tumor necrosis factor-alpha, in vivo. Journal of Clinical Endocrinology and Metabolism 82 4196-4200.

Ohoka N, Yoshii S, Hattori T, Onozaki K \& Hayashi H 2005 TRB3, a novel ER stress-inducible gene, is induced via ATF4-CHOP pathway and is involved in cell death. EMBO Journal 24 1243-1255.

Park H, Ahn Y, Park CK, Chung HY \& Park Y 2003 Interleukin-6 protects MIN6 beta cells from cytokine-induced apoptosis. Annals of the New York Academy of Sciences 1005 242-249.

Pirot P, Ortis F, Cnop M, Ma Y, Hendershot LM, Eizirik DL \& Cardozo AK 2007 Transcriptional regulation of the endoplasmic reticulum stress gene chop in pancreatic insulin-producing cells. Diabetes 56 1069-1077.

Qian B, Wang H, Men X, Zhang W, Cai H, Xu S, Xu Y, Ye L, Wollheim CB \& Lou J 2008 TRI3 is implicated in glucotoxicity- and endoplasmic reticulum-stress-induced beta-cell apoptosis. Journal of Endocrinology 199 407-416.

Ron D \& Walter P 2007 Signal integration in the endoplasmic reticulum unfolded protein response. Nature Reviews. Molecular Cell Biology 8 519-529.

Sandler S, Bendtzen K, Eizirik DL \& Welsh M 1990 Interleukin-6 affects insulin secretion and glucose metabolism of rat pancreatic islets in vitro. Endocrinology 126 1288-1294.

Shimabukuro M, Zhou YT, Levi M \& Unger RH 1998 Fatty acid-induced beta cell apoptosis: a link between obesity and diabetes. PNAS 95 2498-2502.
Song B, Scheuner D, Ron D, Pennathur S \& Kaufman RJ 2008 Chop deletion reduces oxidative stress, improves beta cell function, and promotes cell survival in multiple mouse models of diabetes. Journal of Clinical Investigation 118 3378-3389.

Souza KL, Gurgul-Convey E, Elsner M \& Lenzen S 2008 Interaction between pro-inflammatory and anti-inflammatory cytokines in insulin-producing cells. Journal of Endocrinology 197 139-150.

Verlengia R, Gorjão R, Kanunfre CC, Bordin S, de Lima TM \& Curi R 2003 Effect of arachidonic acid on proliferation, cytokines production and pleiotropic genes expression in Jurkat cells - a comparison with oleic acid. Life Sciences 73 2939-2951.

Wang H, Kouri G \& Wollheim CB 2005 ER stress and SREBP-1 activation are implicated in beta-cell glucolipotoxicity. Journal of Cell Science 118 3905-3915.

Wrede CE, Dickson LM, Lingohr MK, Briaud I \& Rhodes CJ 2002 Protein kinase $\mathrm{B} / \mathrm{Akt}$ prevents fatty acid-induced apoptosis in pancreatic $\beta$-cells (INS-1). Journal of Biological Chemistry 277 49676-49684.

Yamaguchi S, Ishihara H, Yamada T, Tamura A, Usui M, Tominaga R, Munakata Y, Satake C, Katagiri H, Tashiro F et al. 2008 ATF4-mediated induction of 4E-BP1 contributes to pancreatic beta cell survival under endoplasmic reticulum stress. Cell Metabolism 7 269-276.

Received in final form 13 May 2010

Accepted 20 May 2010

Made available online as an Accepted Preprint 20 May 2010 